Acta Theriologica 41 (4): 395-408, 1996.

PL ISSN 0001-7051

\title{
Diet of otters Lutra lutra in central Finland
}

\author{
Risto SULKAVA
}

Sulkava R. 1996. Diet of otters Lutra lutra in central Finland. Acta Theriologica 41: $395-408$.

The diet of otters Lutra lutra (Linnaeus, 1758) in central Finland was studied in 1988-1993 by analysing 1506 spraints. The main components of the diet of otters are fish and amphibians. The most important fishes for otters are small (body length mostly less than $15 \mathrm{~cm}$ ) cyprinids, perches and pikes. The composition of food varies seasonally. In winter amphibians are the most important prey (33.2\% of all food). Perches, pikes and cyprinids are important during all seasons, but in winter small sculpins $(9.8 \%$ of the food) and burbots $(8.9 \%)$ are also important. In spring the most important prey are cyprinids ( $38.7 \%$ of the food). Amphibians are important, especially in the smallest streamlets (in winter, $68.4 \%$ of the food). Otters also eat toads Bufo bufo. In some areas crayfish and mammals are quite important; but for most otters in the study area salmonids, birds, reptiles, insects, mollusks and plants are only occasional food. Most of the otters in the study area live in small forest rivers. In central Finland in winter amphibians and sculpins are of great importance for otters living in small rivers.

University of Joensuu, Department of Biology, Aaponkaari 3, FIN-42800 Haapamäki, Finland

Key words: Lutra lutra, diet, Finland

\section{Introduction}

The European otter Lutra lutra (Linnaeus, 1758) is an endangered species in Europe. In central Finland, however, the otter population has increased in the last nine years (Stjernberg and Hagner-Wahlsten 1991, Sulkava 1993). One of the essential conditions for the otters' survival is diet. Several studies have shown that while fish dominate the diet of otters, there are also great variations in the diet (eg Erlinge 1967, Fairley 1972, Jenkins et al. 1979, Chanin 1981, Adrian and Delibes 1987, Kemenes 1989, Mortensen 1989, Ozolins and Rantins 1992, Brzeziński et al. 1993). Little information has been published concerning on the diet of otters in Finland (eg Skarèn 1992) and in the northern part of Europe overall. So our knowledge about otter foraging and diet in the North of Europe is still incomplete.

The aim of this study, which is part of a long-term project on the ecology of otters in central Finland, was to ascertain the diet of otters. This paper presents the results of research in 1988-1993 on the diet of otters in central Finland. 


\section{Study area}

The study area, which covers about $2800 \mathrm{~km}^{2}$, is situated in the upper tributaries of the Kokemäenjoki river system in central Finland $\left(62^{\circ} 15^{\prime} \mathrm{N}, 24^{\circ} 25^{\prime} \mathrm{E}\right)$. This area includes three main water systems, many small rivers, streamlets and many lakes (Fig. 1). Most of the streams $(69 \%$ of a total of 111 observed places) in the area are less than $5 \mathrm{~m}$ wide and only a few (8.1\%) rivers are more than $10 \mathrm{~m}$ wide. In the study area dystrophic waters are typical, but some oligotrophic and eutrophic waters are also found. The water level in all rivers varies seasonally. This is important for otters because the water level becomes lower in winter, when all lakes and most of the rivers are totally covered by ice. The lowered water level forms tunnels under the ice of the rivers, which can be used by otters. The smallest streamlets $(<2 \mathrm{~m}$ wide) are also important for otters, especially in the winter, when they find hibernating amphibians in the bottom of these.

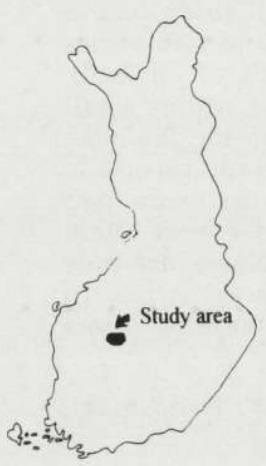

Finland

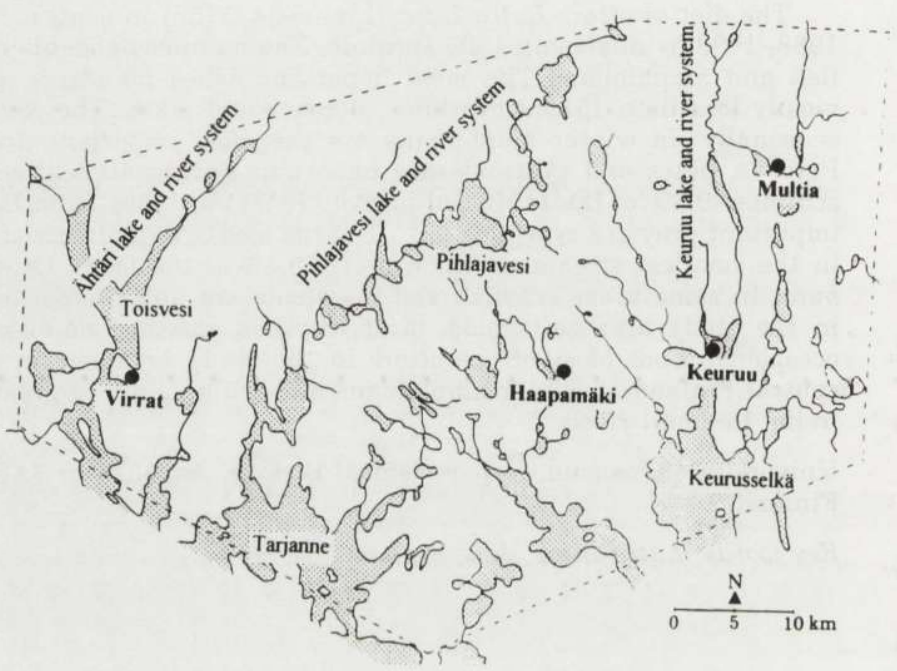

Fig. 1. Map of the study area and its location in Finland. The size of the study area is about 2800 $\mathrm{km}^{2}$. The study area is dominated by small rivers and streamlets (lakes in grey). Most of the streams are covered by ice in normal winters.

In winter the temperature generally drops to below $-20^{\circ} \mathrm{C}$, sometimes to $-35^{\circ} \mathrm{C}$. Normal thickness of snow is about $70 \mathrm{~cm}$, sometimes more than $100 \mathrm{~cm}$ and the snow cover remains in the area from November to April. All rivers flow mainly through forest areas, but there is also some agricultural land (less than $15 \%$ of area) and settlements in the area. There live about 20000 inhabitants in the area. The forests consist mainly of coniferous trees.

\section{Material and methods}

A total of 1506 spraints (scats) were collected in different parts of the study area from 1988 to 1993. Careful field records were kept, eg exact location, width of the river, sprainting date (a sprainting month in the summer), and the running direction of the otter (if known). The date and direction were estimated by snowtracks in the winter, and in summer the same places were examined every month. Running direction was not known in the summer. Spraints were collected every month throughout the 
year. The following months were included in each of the four seasons: spring - April and May, summer - June to August, autumn - September and October, and winter - November to March.

The spraints were dried and remains were identified according to the keys of Eloranta (1975), Webb (1976), Märtz (1987), and Steinmetz and Muller (1988) as well as using reference skeletons and scales of fishes and reference skeletons of other groups. The size of fishes was estimated according to Jenkins et al. (1979) and Wise (1980).

The composition of the otter diet is presented as percentage frequency (PF), relative frequency $(\mathrm{RF})$ and bulk percentages (BP). Percentage frequency shows the percentage of spraints containing a particular prey item. Relative frequency, which is the number of occurrences of an item, is expressed as the percentage of the occurrences of this particular item compared with the total number of occurrences of all items in the sample (sum is $100 \%$ ). Bulk percentage is the number assigned to indicate the importance of a particular item in a spraint and was scored visually of spraint volume. The total score for all items, in each scat is 100 . The values for each item in each spraint are added together and expressed as the bulk percentage (see eg Wise et al. 1981 or Mason and Macdonald 1986). All figures and numbers in the text are presented as bulk percentages.

Significance of the results was tested by analysis of a variance (Scheff-test) after square root and arcsin modifications (Ranta et al. 1994). The microcomputer program SYSTAT was used.

\section{Results}

\section{Composition of the diet in general}

Altogether 1506 spraints were analysed, yielding 3742 prey items from 37 prey species (or other taxons). In the total material fish is the main food of otters (62.9\%). Amphibians (Rana sp./Bufo bufo; $16.5 \%)$ and mammals (11.0\%) are also important food (Fig. 2). In some seasons or areas birds (3.1\%) and crayfish (Astacus

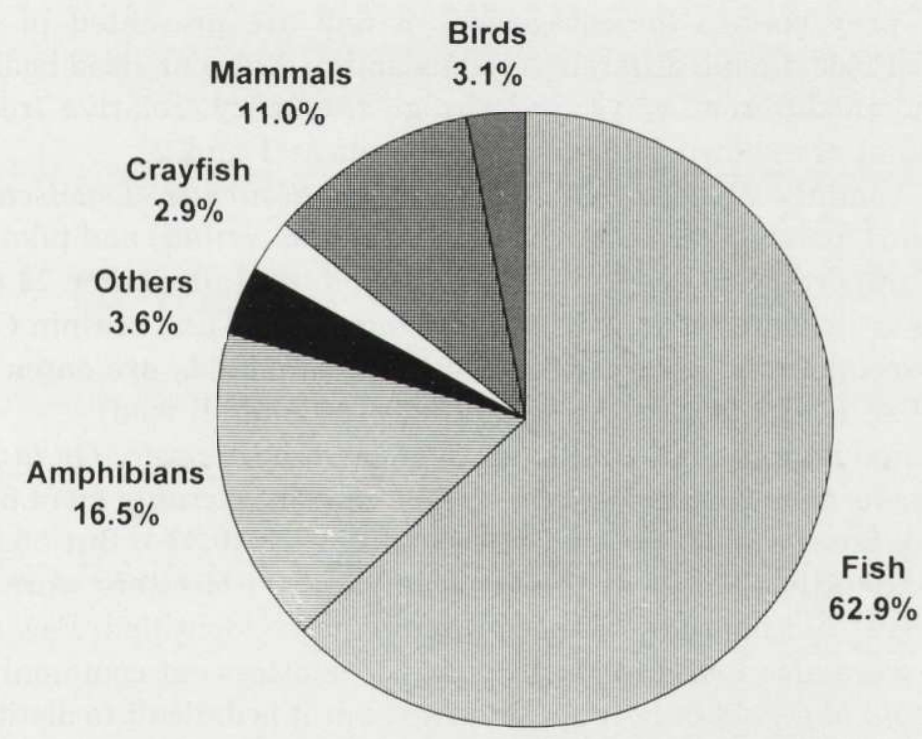

Fig. 2. The food of otters in central Finland in 1988-1993. A whole year and all waters together, as bulk percentages. Sample size: 1506 spraints altogether. 


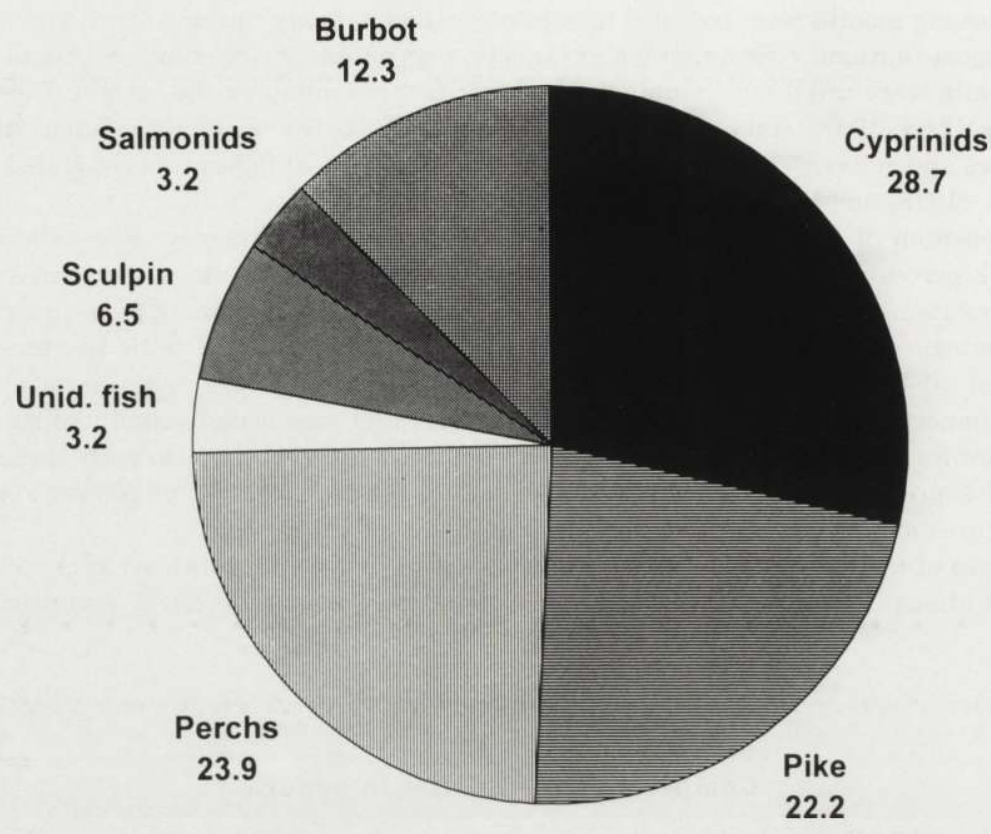

Fig. 3. Different species or groups of fish in the food of otter in central Finland in 1988-1993.

sp.; 2.9\%) are important also. Other sources of food, such as plants, insects, reptiles or molluscs, are not important.

The main prey species (or categories) of fish are presented in Fig. 3. The compositions of food during different seasons and in different sized bodies of water, and presented in different ways (percentage frequency, relative frequency and bulk percentage) are shown in detail in Appendices 1 and 2.

Cyprinids (mainly Rutilus rutilus, Alburnus alburnus, Leuciscus idus and Abramis brama), perch (Perca fluviatilis and Acerina cernua) and pike Esox lucius are the most important fishes in the food of the otter (altogether 74.8\%). During some seasons or in some areas, burbot Lota lota (12.3\%) and sculpin Cottus cottus $(6.5 \%)$ are also important food items. However, salmonids are eaten only rarely (3.2\% of the fish in the food of otters and only $2.0 \%$ of all food).

The identified mammalian species in the food of otters were Ondatra zibethica (31.0\%), Arvicola terrestris (5.5\%), Clethrionomys or Microtus sp.(4.8\%), Neomys fodiens (1.7\%), Sorex sp. (0.7\%), and Microtus agrestis $(0.3 \%)$. But $55.9 \%$ of mammals are not identified. Most of the birds in the food of otters were young wild ducks (Anatidae), but only few of these remains were identified. Few Cinclus cinclus remains were also found in the spraints. The otters eat commonly also venomous toads Bufo bufo, not only frogs Rana sp., but it is difficult to distinguish these species. The identified invertebrates were Dytiscus sp., Asellus sp. and larvae of some Trichoptera species. One snake (Vipera berus or Natrix natrix) was also found. 


\section{Composition of the diet during different seasons}

In the diet of otters in the study area there was much seasonal variation (Figs 4 and 5 and Appendices 1 and 2). In all seasons fish was one of the main foods, but in winter there are many fewer fish in the food of otters than in other seasons $(p<0.001)$.

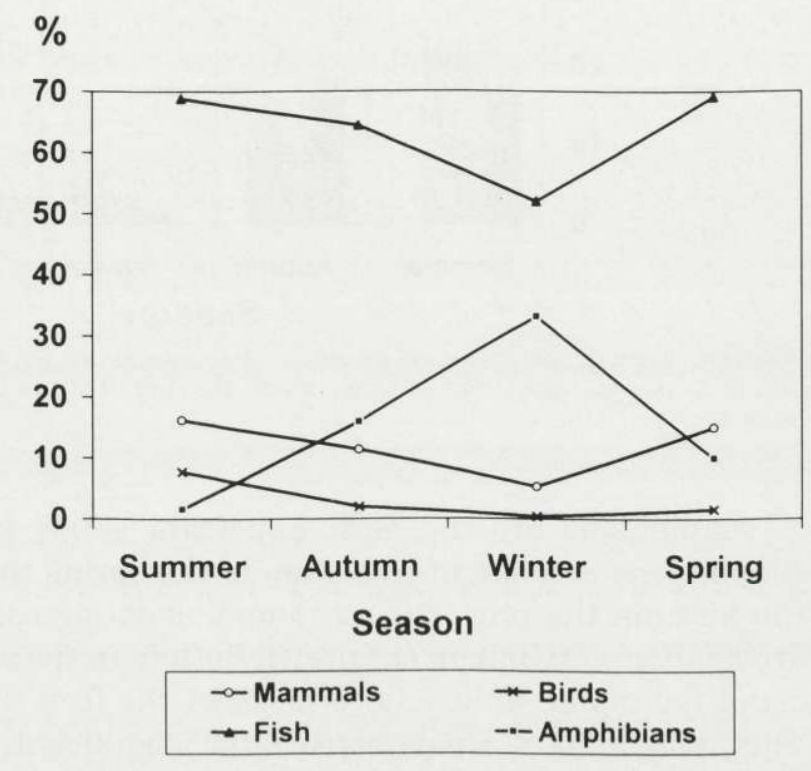

Fig. 4. Seasonal shift in the diet of otters in central Finland in 1988-1993 as bulk percentages. Sample size (total number of spraints): spring 139 , summer 441 , autumn 423 , winter 473 .

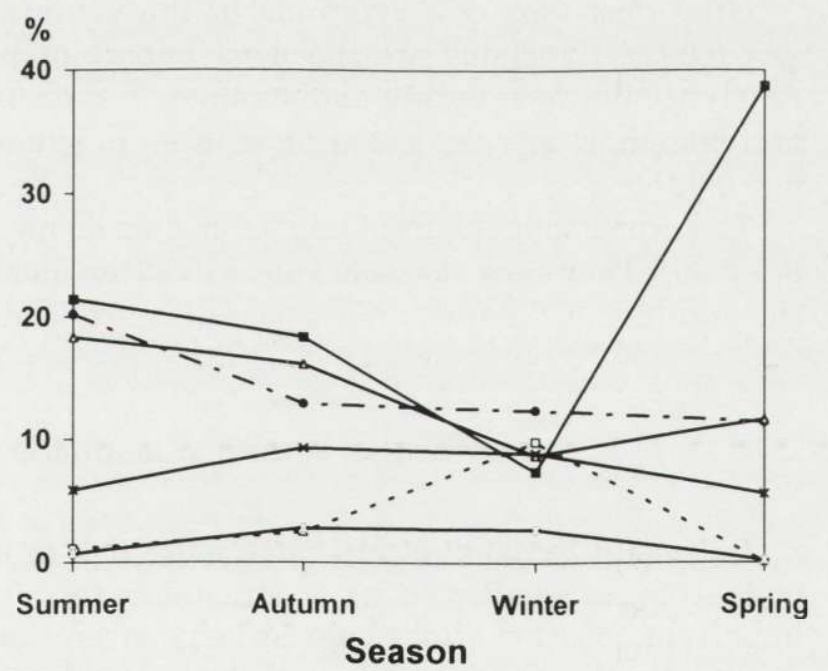

Fig. 5. Seasonal shift of the species or groups of fish in the diet of otters. Sample size as in Fig. 4.

$\begin{array}{lll}\rightarrow \text { - Cyprinids } & \rightarrow-\text { Perch } & \rightarrow \text { Pike } \\ \rightarrow \text { Burbot } & - \text { - Sculpin } & - \text {-Salmonids }\end{array}$




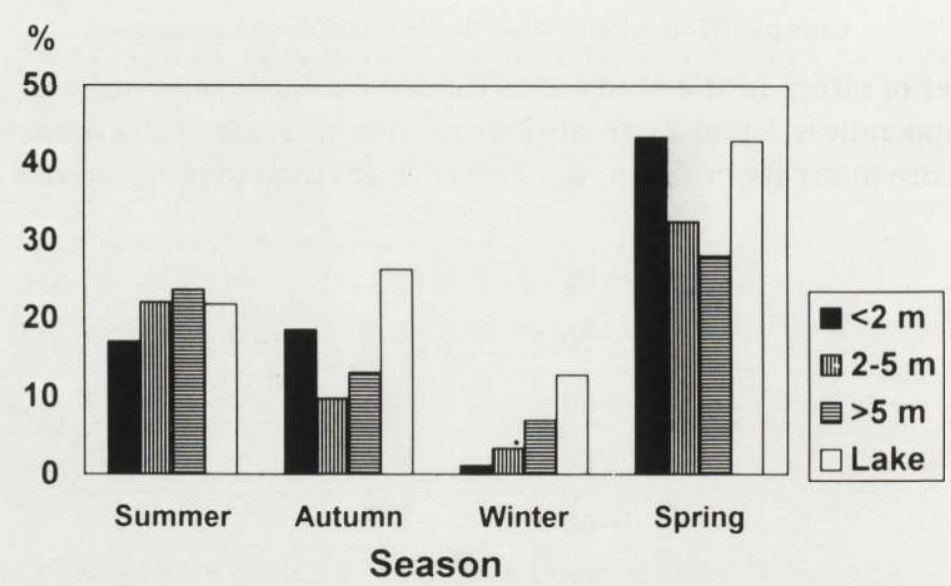

Fig. 6. Seasonal proportions of cyprinids in the diet of otters in different sizes of waters. Sample size as in Fig. 4.

Amphibians are the most important single type of prey in winter (33.2\%). Amphibians are caught less often in the spring than in winter $(p<0.001)$, and in the autumn the proportion of amphibians increase rapidly $(p<0.001)$. Sculpins are another very important prey for otters in the winter. During that season these small fish make up a total of $9.8 \%$ of the food ( $20.1 \%$ in percentage frequency). The numbers of sculpins eaten differ significantly between winter and all other seasons $(p<0.001)$.

Otters eat very few cyprinids in the winter, and more in all other seasons $(p<0.001)$. Cyprinids are the most important prey in the spring, with a clear difference between spring and summer $(p<0.001)$ (Fig. 6). Perches, pikes, birds and mammals are also eaten more often in summer than in winter (in all cases, $p<0.001$ ).

The proportion of burbot and salmonids do not differ between seasons (for both $p>0.05$ ). There are also some parasites (the identified items were all Cestoda) in the spraints of the otter. Most parasites are found in spring $(p<0.001)$.

\section{Composition of the diet in different sizes of waters}

In central Finland, otters catch more fish in lakes and in large rivers ( $>5 \mathrm{~m}$ wide) than in smaller rivers or streamlets $(p<0.001)$. In winter fish is the most important food for otters only in large rivers and near lakes (where otters can dive under the ice of the lake). Sculpins are the most important prey in big rivers (23.6\% of food), and near lakes (10.1\%) they are nearly as important prey as perch, pike or cyprinids. No sculpins live in the smallest ( $<2 \mathrm{~m}$ wide) streamlets (App. 2). 


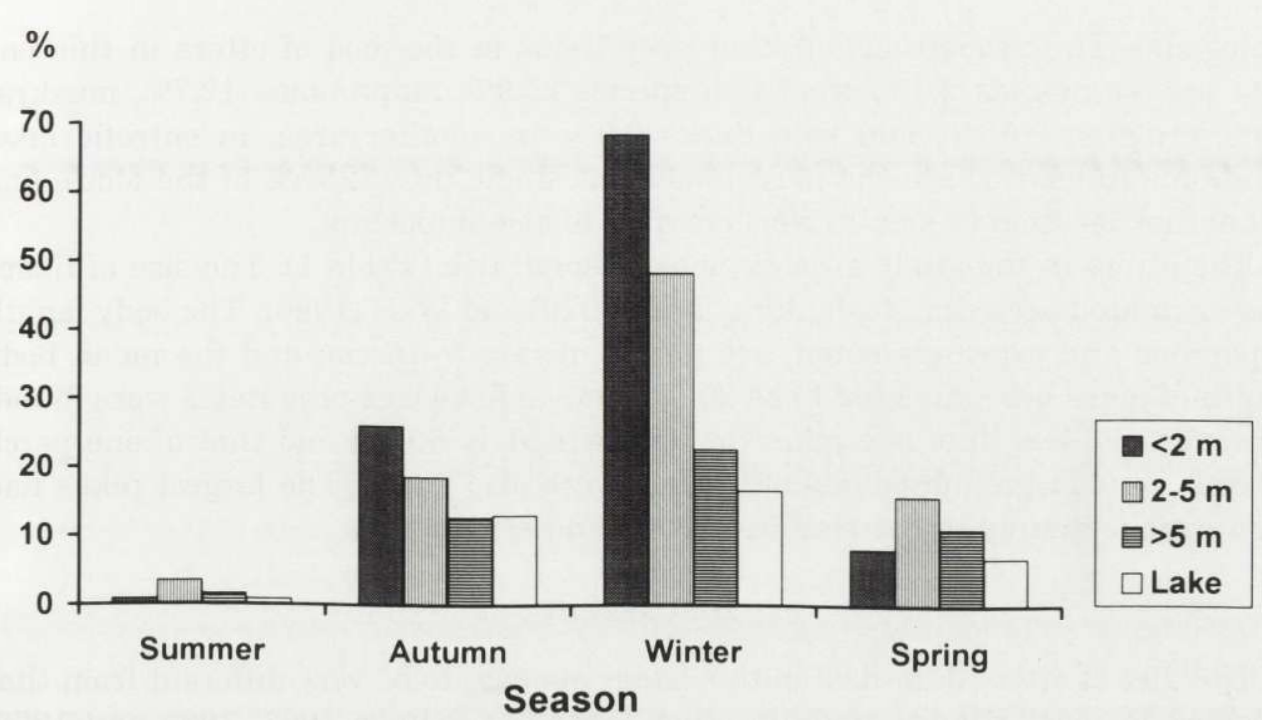

Fig. 7. Seasonal proportions of amphibians in different sizes of waters (mean width of the river) as bulk percentages in central Finland in 1988-1993. Sample size as in Fig. 4.

Amphibians are the most important prey in the winter both in the smallest streamlets $(68.4 \%)$ and in small rivers (2-5 m wide) (48.3\% of food; Fig. 7 ).

The diet of otters also differs between rivers and between areas of the same river or stream. The spraints were collected in all rivers and all parts of the study area, and 12 different kinds of areas, at a great distance, were on critical examination (Appendix 3). For example in one large river (near a lake) otters eat mostly sculpins ( $\mathrm{BP}=29.0 \%$ of food) and small burbots $(\mathrm{BP}=22.0 \%)$. The body length of burbots is $5-15 \mathrm{~cm}$ and that of sculpins less than $8 \mathrm{~cm}$. In this area there are always very many other prey items available. It is a fishing area (for example pike, perch, cyprinids and introduced salmonids) and there live muskrats and many species of wild ducks also (it is a well-known bird area among orni-

Table 1. The mean length $( \pm$ SD) of scale and vertebra $(\mathrm{mm})$ of the different fish groups in the food of otter in central Finland. LV - length of vertebra, LS length of scale, $n$-number of measured vertebra or scales.

\begin{tabular}{lcccr}
\hline Taxon & LV & $n$ & LS & $n$ \\
\hline Percidae & $1.6 \pm 0.60$ & 190 & $2.3 \pm 0.95$ & 375 \\
Esox lucius & $1.9 \pm 0.98$ & 304 & $5.0 \pm 2.06$ & 221 \\
Cyprinidae & $2.4 \pm 1.12$ & 186 & $6.4 \pm 2.27$ & 256 \\
Lota lota & $2.2 \pm 0.83$ & 331 & - & 0 \\
Unidentified fish & $2.1 \pm 0.91$ & 17 & $3.3 \pm 1.77$ & 2 \\
Total & 2.1 & 1072 & 4.2 & 879 \\
\hline
\end{tabular}


thologists). The proportions of other prey items in the food of otters in this one area are: salmonids $2.4 \%$, other fish species $25.9 \%$, amphibians $12.7 \%$, muskrat $8.0 \%$, crayfish $<0.1 \%$, and wild ducks $0.0 \%$. In another area, in eutrofic lake, mammals (muskrat) are the most important single prey (25.8\% of the food), and in another location (a small river) crayfish is also important.

The otters in the study area eat mostly small fish (Table 1). The size of fishes was estimated according to Jenkins et al. (1979) and Wise (1980). The body length of perches and cyprinids eaten, are nearly always $5-15 \mathrm{~cm}$, and the mean body length of pikes are estimated to be $20 \mathrm{~cm}$. Only a few large prey items were found. However, the length of one pike was approximately $60 \mathrm{~cm}$ and that of one perch $30 \mathrm{~cm}$. Some large individuals of breams were also found. The largest pikes had been caught mainly in the smallest rivers and streamlets.

\section{Discussion}

The diet of otters described in this paper appears to be very different from that reported in most studies made in other areas (eg Erlinge 1967, 1969 and 1972, Webb 1975, Kruuk and Hewson 1978, Jenkins et al. 1979, Jenkins and Harper 1980, Wise et al. 1981, Adrian and Delibes 1987, Kemenes 1989, Kruuk and Moorhouse 1990, Beja 1991). In only a few studies has it been reported that otters eat large numbers of amphibians (Fairley 1972, Macdonald and Mason 1982, Skarèn and Kumpulainen 1986, Laanetu 1989, Weber 1990, Ozolins and Rantins 1992, Skarèn 1992, Brzeziński et al. 1993), and most of these reports are from either the northernmost or the southernmost latitudes. In the cold season amphibians were reported to be the most important component of the diet of otters in Latvia (Ozolins and Rantins 1992) and in Białowieża National Park, Poland (Brzeziński et al. 1993). Most of the otters in central Finland live in small rivers or streamlets in the winter, and during this season eat mainly amphibians. In all of these areas (Latvia, Białowieża and central Finland) the most numerous flowing waters are small forest rivers or streamlets. In the past, these types of forest rivers were perhaps the most common watercourses on the lowlands of Europe, and this type of food composition (Ozolins and Rantins 1992, Brzeziński et al. 1993, this paper) was probably the most important for otters over large areas of Europe.

Erlinge (1968) and Jenkins et al. (1979) reported that in captivity otters do not eat toads Bufo bufo. Weber (1990), Beja (1991) and Brzeziński et al. (1993), however, found that some toads were eaten by wild otters. In this study no remains of toads were identified in spraints, but otters do eat toads. Otters are very skilled in skinning toads, and these separate skins with skulls were found when the tracks of otters were followed. Because the otters often do not eat the toad skulls, it is difficult to distinguish between the bones of toads and other amphibians. Based on my observations I believe that the otters in central Finland eat almost as many toads as other amphibians, and this may also be the case in other northern areas. 
Amphibians are very common, and when they hibermate in the bottom of rivers, they are easy prey for otters. Otters often use their muzzles to turn over stones and wood to seek out amphibians, crayfish, sculpins and small burbots (Sulkava and Sulkava 1989, Sulkava 1993). All these prey species are easy to catch, and when plenty of this kind of prey is available, it is unprofitable for otters to try to catch larger and fast fishes like salmonids.

Even though spring is the breeding time for amphibians, there are fever amphibians in the otter diet in spring than in the winter. The breeding season is, however, quite short, and Rana-species in particular breeds in various small ponds rather than in rivers or lakes. Perhaps otters do not easily find these breeding ponds. After breeding, amphibians leave the rivers, lakes and ponds and return in the autumn.

In central Finland otters eat fish least frequently in the winter, a result that supports the findings of Skarèn (1992) and Brzeziński et al. (1993). However, it also contradicts the findings of many previous studies (eg Erlinge 1967, Webb 1975, Chanin 1985). The reason that otters eat fever fish in the winter is probably because lakes are totally covered by ice, and in the rivers are fewer fish available at that time of year.

In many areas small fishes are typical prey for otters (Jenkins et al. 1979, Wise et al. 1981, Adrian and Delibes 1987, Kemenes 1989, Mortensen 1989, Ozolins and Rantins 1992, Skarèn 1992, Brzeziński et al. 1993). In contrast, some studies have found that most of the fishes eaten by otters were quite large (Erlinge 1969, Carss et al. 1990). Mortensen (1989) and Skarèn (1992) described small sculpins as relief food in the winter. The results of the present study do not, however, support that theory. For example, otters eat mainly sculpins and small burbots, even in one area where there are always a large number of (introduced) salmonids and other fishes as well as muskrats and overwintering wild ducks available. Sculpins and small burbots are such easy prey for otters that when there are plenty of these species available, it is profitable for the otters to concentrate on these small species. In the rivers of central Finland the most numerous preys found during electrofishing were sculpins (Anon. 1987).

The largest fishes in the food of otters were found in the smallest rivers, probably because these fast fishes cannot escape from the otters in small and very shallow rivers. Chanin (1985) also reported that otters more often fail in their hunting if the water is deep.

One jawless (Cyclostomata) species (Lampetra planeri) also lives in the study area. This species is common, but hard to find if it is a food item for otters.

In conclusion, this study supports previous observations that habitat and available food resources largely determine the otter diet and foraging habits (Erlinge 1967 and 1972, Webb 1975, Jenkins et al. 1979, Chanin 1985, Mason and Macdonald 1986, de Silva 1991). According to these results in central Finland, small fishes and amphibians are important food items for otters in small forest rivers. 
Nowadays amphibian populations are decreasing throughout the World, and in Finland many original small forest rivers and streamlets are destroyed by ditching every year. Disappearance of these food supplies and suitable habitats may be a threat for the otter population, although the current otter population in the study area is dense and viable.

Acknowledgements: I am grateful to Dr H. Hyvärinen and Dr S. Sulkava for their comments on the manuscript. I would like to thank Dr J. Von Weissenberg and S. Huohvanainen for their help to correcting the English language of this paper. I would thank also P. Sulkava and all my field assistants for their help in the field work.

\section{References}

Adrian M. J. and Delibes M. 1987. Food habits of the otter (Lutra lutra) in two habitats of the Donaña National Park, SW Spain. Journal of Zoology, London 211: 399-406.

Anon. 1987. [Electrofishing in central Finland]. National Board of Water and Environment of Finland. Unpublished results of electrofishing. Office of central Finland, Jyväskylä. [In Finnish]

Brzeziński M., Jędrzejewski W. and Jędrzejewska B. 1993. Diet of otters (Lutra lutra) inhabiting small rivers in Białowieża National Park, eastern Poland. Journal of Zoology, London 230: 495-501.

Beja P. R. 1991. Diet of otters (Lutra lutra) in closely assosiated freshwaters, brackish and marine habitats in South-West Portugal. Journal of Zoology, London 225: 141-152.

Carss D., Kruuk H. and Conroy J. W. H. 1990. Predation an adult atlantic salmon, Salmo salar L., by otters, Lutra lutra (L.), within the River Dee System, Aberdeenshire, Scotland. Journal of Fish Biology 37: 935-944.

Chanin P. 1981. The diet of the otter and its relations with the feral mink in two areas of South-West England. Acta Theriologica 26: 83-95.

Chanin P. 1985. The natural history of otters. Facts On File, Inc. London: 1-179.

Eloranta A. 1975. [Determining of the age of fishes]. Finlands Fishing Assosiation no. 60. Vammalan Kirjapaino: 1-68. [In Finnish]

Erlinge S. 1967. Food habits of the fish otter (Lutra lutra L.) in South Swedish habitats. Viltrevy 4: 371-443.

Erlinge S. 1968. Food studies on captive otters (Lutra lutra L.). Oikos 19: 259-270.

Erlinge S. 1969. Food habits of the otter Lutra lutra L. and mink Mustela vison Schreber in a trout water in southern Sweden. Oikos 20: 1-7.

Erlinge S. 1972. Interspecific relations between otter Lutra lutra and mink Mustela vison in Sweden. Oikos 23: 327-335

Fairley J. S. 1972. Food of otters (Lutra lutra) from Co. Galvay, Ireland and notes on aspects of their biology. Journal of Zoology, London 166: 469-474.

Jenkins D. and Harper R. J. 1980. Ecology of otters in northern Scotland. II. Analyses of otter (Lutra lutra) and mink (Mustela vison) faeces from Deeside, N.E. Scotland in 1977-78. Journal of Animal Ecology 49: 737-754.

Jenkins D., Walker J. G. K. and McCowan D. 1979. Analyses of otter (Lutra lutra) faeces from Deeside, W.E. Scotland. Journal of Zoology, London 187: 235-244.

Kemenes I. 1989. A comparative study on the food composition of otters (Lutra lutra L.) at lakes and fish-ponds in Hungary. [In: Populationsökologie marderartiger Säugetiere. M. Stubbe, ed]. Wissenschaftliche Beiträge, Universität Halle 1989/37: 77-88.

Kruuk H. and Hewson R. 1978. Spacing and foraging of otters (Lutra lutra) in a marine habitat. Journal of Zoology, London 185: 205-212.

Kruuk H. and Moorhouse A. 1990. Seasonal and spatial differences in food selection by otters (Lutra lutra) in Shetland. Journal of Zoology, London 221: 621-637. 
Laanetu N. 1989. Zur Ökologie des Fischotters Lutra lutra (L.1758) in Estland. [In: Populationsökologie margerertiger Säugetiere. M. Stubbe, ed]. Wisseschaftliche Beiträge, Universität Halle 1989/37: 59-70.

Macdonald S. M. and Mason C. F. 1982. Otters in Greece. Oryx 16: 240-244.

Mason C. F. and Macdonald S. M. 1986. Otters: ecology and conservation. Cambridge University Press, Cambridge: 1-236.

Mortensen P. 1989. [Distribution and spraint analysis of otter in Råneälvens watersystem]. Viltnytt 27: 40-50. [In Swedish]

Märtz R. 1987. Gewöll- und Rupfungskunde. Akademic-Verlag, Berlin: 1-398.

Ozolins J. and Rantins M. 1992. Einige Voraussezungen zur hentigen Bestandsentwicklung und zur Verbreitung des Fischotters Lutra lutra (L.) in Lettland. [In: Semiaquatische Säugetiere. R. Schröpfer, M. Stubbe and D. Heidecke, eds]. Wissenschaftliche Beiträge, Universität Halle 1992: 365-384. [Summary in English]

Ranta E., Rita H. and Kouki J. 1994. Biometrics. Yliopistopaino. Helsinki, 1-569. [In Finnish]

Silva P. K., de 1991. Aspects of behaviour and ecology of Old World otters - A review. [In: Proceedings of the 5th, International otter colloquim. Habitat 6. C. Reuther and R. Röchert, eds]. GN - Gruppe Natwischutz GmbH, Hankensbuttel: 95-106.

Skarèn U. 1992. [Food of otter in North Savo, Finland]. Savon Luonto 23: 38-47. [In Finnish]

Skarèn U. and Kumpulainen J. 1986. Recovery of the otter Lutra lutra (L.,1758) population in North Savo, Central Finland, with an analysis of environmental factors. Lutra 29: 117-140.

Stjernberg T. and Hagner-Wahlsten N. 1991. The distribution of the otter (Lutra lutra L.) in Finland in 1975 and 1985. [In: Proceedings of the 5th international otter colloquium. Habitat 6. C. Reuther and R. Röchert, eds]. GN - Gruppe Natwischutz GmbH, Hankensbuttel: 37-43.

Steinmetz B. and Muller R. 1988. Atlas of scales and other bony structures of non-salmonid freshwater fish. Food and Agriculture Organisation (FAO). European Inland Fisheries Advisory Commission (EIFAC). Report: 1-45.

Sulkava R. 1993. [Status and ecology of the otter (Lutra lutra L.) in central Finland in 1985-1993 and the short survey methods in evaluating the status]. Unpublished M Sc thesis. University of Joensuu, Joensuu: 1-85. [In Finnish]

Sulkava P. and Sulkava R. 1989. [Distribution and ecology of otters in central Finland]. Luonnon Tutkija 93: 124-129. [In Finnish with abstract in English]

Webb J. W. 1975. Food of the Otter (Lutra lutra) on the Sommerset Levels. Journal of Zoology, London 177: 486-491.

Webb J. B. 1976. Otter spraint analysis. An occasional publication of the Mammal Society: 1-13.

Weber J.-M. 1990. Seasonal exploitation of amphibians by otters (Lutra lutra) in North-East Scotland. Journal of Zoology, London 220: 641-651.

Wise M. H. 1980. The use of fish vertebrae in scats for estimating prey size of otters and mink. Journal of Zoology, London 192: 25-31.

Wise M. H., Linn I. J. and Kennedy C. R. 1981. A comparison of the feeding biology of mink Mustela vison and otter Lutra lutra. Journal of Zoology, London 195: 181-213.

Received 17 January 1996, accepted 31 July 1996. 


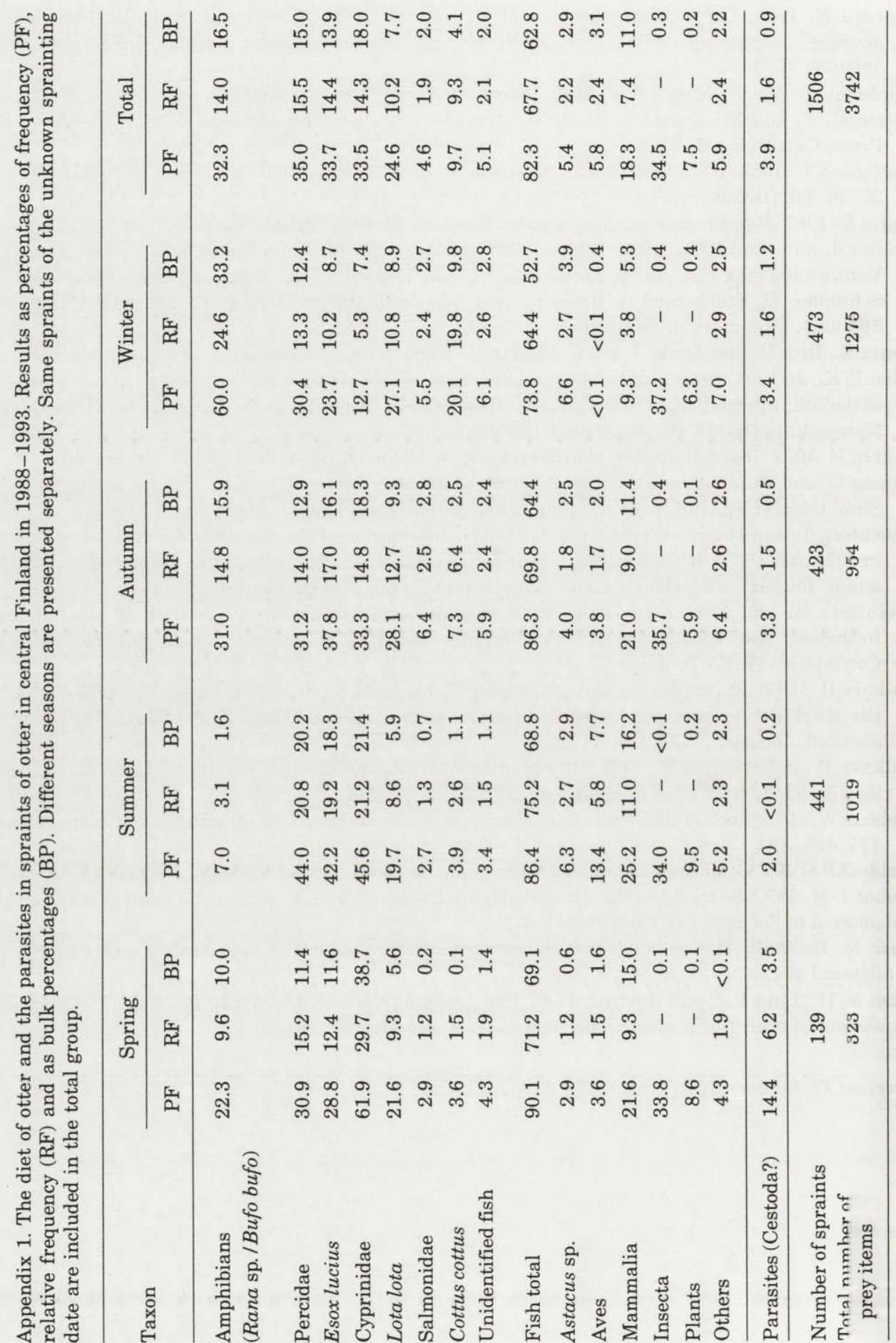




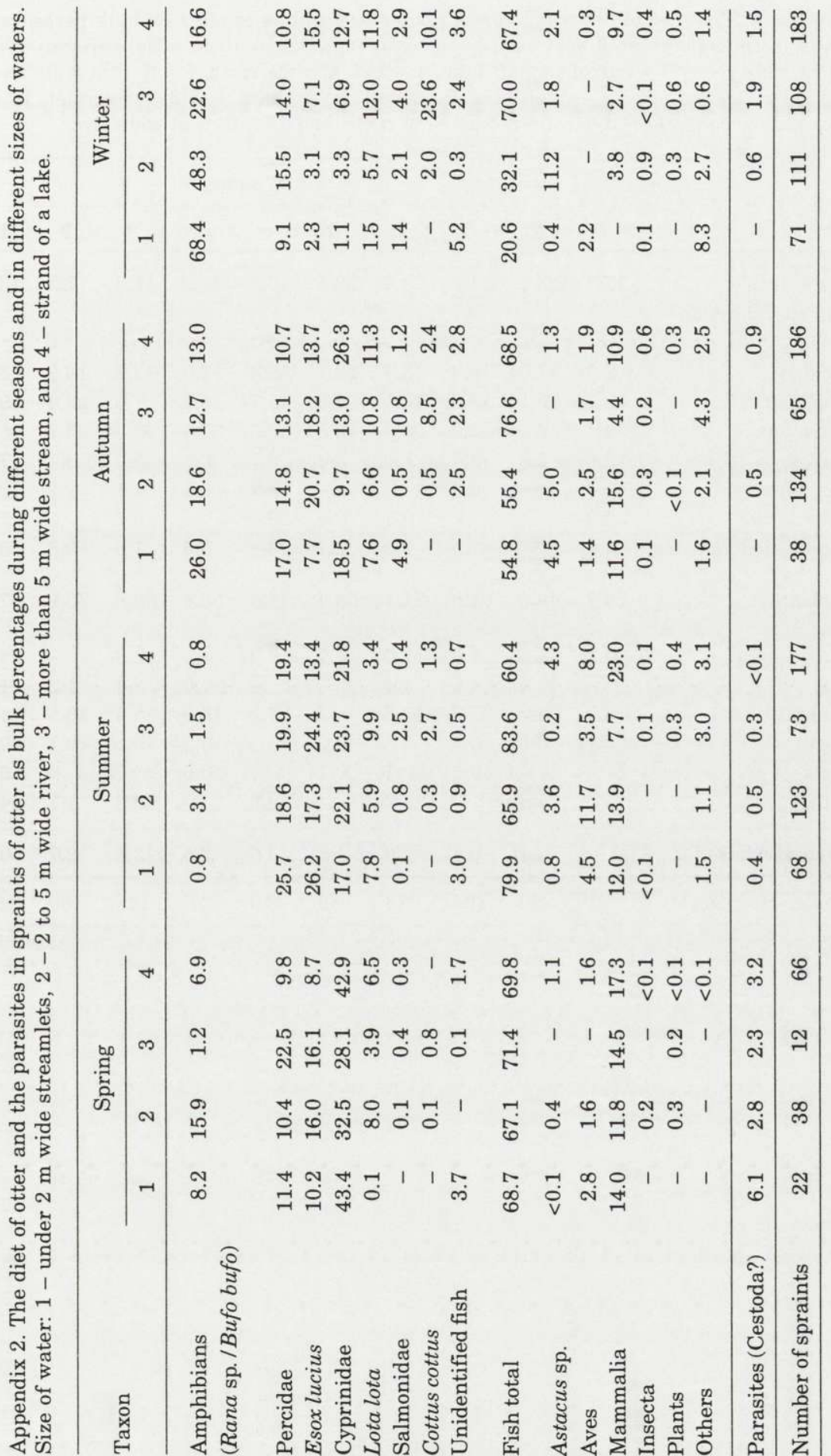


Appendix 3. The diet of otter and the parasites in spraints of otter as bulk percentages in different waters in central Finland. Waters: 1 - big river (more than $10 \mathrm{~m}$ wide) between two big lakes, $2-$ $2-5 \mathrm{~m}$ wide river, 3 - eutrofic small lake, $4-2-5 \mathrm{~m}$ wide river, $5-2-5 \mathrm{~m}$ wide river, $6-5-10 \mathrm{~m}$ wide river, 7 - big lake, 8 - small lake, 9 - small (less than $2 \mathrm{~m}$ wide) streamlet, $10-5-10 \mathrm{~m}$ wide, very shallow river, $11-$ dystrofic $2-5 \mathrm{~m}$ wide river, and $12-2-5 \mathrm{~m}$ wide river.

\begin{tabular}{|c|c|c|c|c|c|c|c|c|c|c|c|c|}
\hline \multirow{2}{*}{ Taxon } & \multicolumn{12}{|c|}{ Waters } \\
\hline & 1 & 2 & 3 & 4 & 5 & 6 & 7 & 8 & 9 & 10 & 11 & 12 \\
\hline $\begin{array}{l}\text { Amphibians } \\
\text { Rana sp./Bufo bufo }\end{array}$ & 12.7 & 23.7 & 1.3 & 9.0 & 23.5 & 10.8 & 14.9 & 11.4 & 7.2 & 13.2 & 23.3 & 30.3 \\
\hline Percidae & 2.3 & 17.0 & 4.4 & 13.9 & 29.7 & 19.8 & 7.0 & 13.2 & 16.2 & 5.5 & 16.4 & 16.8 \\
\hline Esox lucius & 10.7 & 20.1 & 19.8 & 16.0 & 4.6 & 15.7 & 9.9 & 7.0 & 22.4 & 9.1 & 12.7 & 12.1 \\
\hline Cyprinidae & 9.4 & 6.5 & 23.9 & 28.6 & 16.8 & 12.3 & 37.4 & 38.8 & 25.7 & 25.6 & 2.8 & 10.5 \\
\hline Lota lota & 22.0 & 6.0 & 11.7 & 8.9 & 3.4 & 2.7 & 0.3 & 5.0 & 3.7 & 7.2 & 10.7 & 5.4 \\
\hline Salmonidae & 2.4 & - & 0.3 & - & - & 3.7 & $<0.1$ & 1.1 & 2.2 & 15.6 & 2.9 & - \\
\hline Cottus cottus & 29.0 & - & - & 0.7 & 0.5 & 20.3 & - & 0.1 & - & 1.2 & 1.0 & 0.1 \\
\hline Unidentified fish & 3.5 & - & 1.5 & 2.9 & 3.1 & 0.8 & 3.6 & 1.6 & 3.8 & 3.0 & $<0.1$ & - \\
\hline Fish total & 79.2 & 49.5 & 61.6 & 71.1 & 58.1 & 75.3 & 58.0 & 66.8 & 73.8 & 67.2 & 46.6 & 45.0 \\
\hline Astacus sp. & $<0.1$ & - & 5.6 & 1.0 & 9.7 & 0.2 & - & 2.8 & - & 1.1 & - & 1.2 \\
\hline Aves & - & 12.4 & 4.9 & 4.4 & - & - & 7.0 & 3.4 & 1.2 & 1.3 & 6.4 & 3.0 \\
\hline Mammalia & 8.0 & 8.0 & 25.8 & 10.8 & 6.7 & 7.3 & 16.9 & 8.4 & 13.5 & 11.3 & 19.0 & 19.3 \\
\hline Insecta & - & 0.6 & $<0.1$ & 0.3 & 0.2 & $<0.1$ & 0.2 & 0.1 & $<0.1$ & $<0.1$ & - & 0.6 \\
\hline Plants & - & - & 0.5 & 0.1 & 0.1 & - & 0.5 & 0.7 & - & 0.9 & - & - \\
\hline Other & - & 5.8 & - & 1.4 & - & 2.9 & - & 3.3 & 1.7 & 4.2 & 4.7 & 0.6 \\
\hline Parasites (Cestoda?) & - & - & 0.4 & 2.0 & 1.8 & 3.6 & 2.5 & 3.1 & 2.7 & 0.8 & - & - \\
\hline Number of spraints & 71 & 60 & 106 & 78 & 39 & 56 & 28 & 142 & 60 & 66 & 34 & 34 \\
\hline
\end{tabular}

